\title{
Możliwość ustawowego ograniczenia dostępu do pornografii w internecie w świetle przepisów Unii Europejskiej z zakresu swobód przepływu przedsiębiorczości i świadczenia usług (art. 49 i 56 TFUE) oraz odpowiedzialności usługodawców będących pośrednikami (art. 15 dyrektywy o handlu elektronicznym) ${ }^{1}$
}

The possibility of establishing legal restrictions concerning an access to pornography in the Internet from the perspective of the European Union law on the freedom of entrepreneurship: The subject of the opinion is the evaluation of establishing legal restrictions concerning access to pornography, in particular blocking and disabling such contents in $3 \mathrm{G}$ and $4 \mathrm{G}$ networks, as well as providing, by a provider of Internet services, with tools for carrying out the above activities. The author of the opinion points out that no provisions of the EU law prohibit actions aimed at counteracting and detecting pornography in the Internet.

Keywords: internet, pornography, internal market, European Union Słowa kluczowe: internet, pornografia, rynek wewnętrzny, Unia Europejska

Opinia prawna dotycząca możliwości ustawowego ograniczenia dostępu do pornografii $w$ Internecie $w$ świetle przepisów Unii Europejskiej z zakresu swobód przepływu przedsiębiorczości i świadczenia usług (art. 49 i 56 Traktatu o funkcjonowaniu Unii Europejskiej) oraz odpowiedzialności usługodawców będących pośrednikami (art. 15 dyrektywy o handlu elektronicznym sporządzona 15 stycznia 2019 r. na zlecenie posła Klubu Parlamentarnego Prawo i Sprawiedliwość; BAS-WAPM 1866/18. 


\section{Przedmiot opinii}

Opinia dotyczy możliwości ustawowego ograniczenia dostępu do pornografii w internecie w świetle przepisów Unii Europejskiej z zakresu:

- traktatowych swobód rynku wewnętrznego, w szczególności przepływu przedsiębiorczości i świadczenia usług (art. 49 i art. 56 Traktatu o funkcjonowaniu Unii Europejskiej, dalej: TFUE) i

- odpowiedzialności usługodawców będących pośrednikami (art. 15 dyrektywy 2000/31/WE Parlamentu Europejskiego i Rady z 8 czerwca 2000 r. w sprawie niektórych aspektów prawnych usług społeczeństwa informacyjnego, w szczególności handlu elektronicznego w ramach rynku wewnętrznego (Dz.Urz. UE L 178 z 17 lipca 2000 r., s. 1, dalej: dyrektywa).

\section{Możliwość ustawowego ograniczenia dostępu do pornografii w internecie w świetle przepisów Unii Europejskiej z zakresu swobód rynku wewnętrznego, w szczególności przepływu przedsiębiorczości i świadczenia usług (art. 49 i art. 56 TFUE)}

Ustanowienie rynku wewnętrznego, rozumianego jako obszar bez granic wewnętrznych, na którym zapewniony jest swobodny przepływ towarów, osób, usług i kapitału, to jeden z celów ustanowienia i funkcjonowania UE (art. 3 ust. 1, art. 26 ust. 2 TFUE). Spośród traktatowych swobód rynku wewnętrznego możliwość ustawowego ograniczenia dostępu do pornografii w internecie wymaga przeanalizowania w świetle przepisów traktatowych z zakresu swobód przepływu przedsiębiorczości i świadczenia usług (art. 49 i art. 56 TFUE). Przedmiot opinii uzasadnia również odwołanie się do przepisów traktatowych dotyczących swobody przepływu towarów (art. 34 TFUE).

\section{Swoboda przepływu przedsiębiorczości (art. 49 i nast. TFUE)}

Swoboda przedsiębiorczości, której ramy wyznacza art. 49 i dalsze TFUE, oznacza uprawnienie usługodawców z innych państw członkowskich do podejmowania i prowadzenia działalności gospodarczej na własny rachunek w państwach członkowskich innych niż państwa ich pochodzenia, na tych samych warunkach, które przewidują przyjmujące państwa członkowskie dla własnych podmiotów. Aby zagwarantować tę swobodę, przyjmujące państwa członkowskie zobowiązane są znosić wszelkie ograniczenia w podejmowaniu i prowadzeniu stałej działalności gospodarczej przez osoby fizyczne i osoby prawne z innych państw członkowskich, jeśli restrykcji tych nie można usprawiedliwić istotnym interesem publicznym. Swoboda przedsiębiorczości oznacza zatem nie tylko zapewnienie równego traktowania podmiotów pochodzących $\mathrm{z}$ innych państw członkowskich, lecz również możliwie pełną liberalizację zasad prowadzenia transgra- 
nicznej działalności gospodarczej. W ujęciu podmiotowym swoboda przedsiębiorczości przysługuje osobom fizycznym - obywatelom państw członkowskich UE i osobom prawnym pochodzącym z tych państw. Przedmiotowy zakres tej swobody obejmuje natomiast działalność, która ma charakter odpłatny, stały, samodzielny i transgraniczny. Trybunał Sprawiedliwości nakazuje interpretować pojęcie „przedsiębiorczość” szeroko, jako oznaczające: możliwość uczestniczenia przez podmiot pochodzacy z jednego z państw UE, w sposób trwały i nieprzerwany, w życiu gospodarczym państwa członkowskiego innego niż jego państwo pochodzenia i czerpania z tego tytułu korzyści (sprawa C-384/08, Attanasio, pkt 36).

Przedmiot opinii wymaga wskazania, że w myśl art. 52 TFUE państwa członkowskie mogą ograniczyć lub wyłączyć swobodę przedsiębiorczości świadczonej przez osoby fizyczne lub prawne pochodzące z innych państw członkowskich UE, jeżeli jest to konieczne dla zapewnienia określonych dóbr publicznych, tj. ochrony porządku publicznego, bezpieczeństwa publicznego lub zdrowia publicznego. Definicje tych dóbr, których ochrona uzasadnia ograniczenie lub wyłączenie swobody przedsiębiorczości, nie zostały ustalone w przepisach UE, a o ich znaczeniu decydują państwa członkowskie. Stosowanie przez państwa członkowskie wyjątków od traktatowej swobody przedsiębiorczości podlega kontroli sprawowanej przez Trybunał Sprawiedliwości (sprawa C-268/99, Jany i in., pkt 60) i wymaga spełniania ustanowionych w tym zakresie wymogów. Trybunał stoi na stanowisku, że aby ograniczenie lub wyłączenie traktatowej swobody rynku wewnętrznego było dopuszczalne w świetle prawa UE, musi ono: 1) mieć na celu ochronę nadrzędnego interesu publicznego ustalonego w traktatach lub w jego orzecznictwie, 2) być proporcjonalne względem celu, któremu ma służyć i 3) być niedyskryminacyjne, tj. dotyczyć w takim samym zakresie wszystkich podmiotów działających w danym państwie członkowskim - krajowych oraz pochodzących z innych państw członkowskich. Wprowadzane przez państwa członkowskie ograniczenia lub wyłączenia swobód rynku wewnętrznego nie mogą ponadto być ustalane dla celów czysto gospodarczych (sprawa 352/85, Bond, pkt 34).

Jeżeli zatem w danym państwie członkowskim obowiązują lub mają być wprowadzone przepisy ograniczające lub zakazujące świadczenia działalności gospodarczej związanej z działalnością pornograficzną w internecie, to prawo UE dopuszcza rozszerzenie zakresu tych ograniczeń na podmioty pochodzące z innych państw członkowskich.

\section{Swoboda przepływu usług (art. 49 i nast. TFUE)}

Jeżeli natomiast chodzi o swobodę świadczenia usług, to ze swobodą świadczenia przedsiębiorczości łączy ją kilka cech. Obydwie swobody stanowią na gruncie prawa UE konkretyzację zasady niedyskryminacji ze względu na przynależność państwową. Jednakowy jest krąg ich beneficjentów (osoby fizyczne i prawne pochodzące $z$ tych państw) oraz przedmiotowej działalności, bowiem 
usługodawca, prowadząc działalność gospodarczą, może podlegać jednej lub drugiej ze swobód, oferując na terytorium goszczącego państwa członkowskiego dokładnie te same usługi (działalność gospodarczą). Elementem odróżniającym te swobody jest element stałości prowadzonych usług. W przypadku swobody przedsiębiorczości pochodzący z innego państwa członkowskiego usługodawca w sposób stały i ciągły uczestniczy w życiu gospodarczym przyjmującego państwa członkowskiego, a uzyskując zyski, przyczynia się do gospodarczego i społecznego przenikania w UE w danej dziedzinie. Natomiast w przypadku swobody świadczenia usług pochodzący z innego państwa członkowskiego usługodawca przemieszcza się do innego państwa członkowskiego z zamiarem prowadzenia działalności gospodarczej w sposób przejściowy. Tymczasowy charakter działalności gospodarczej jest oceniany w świetle czasu trwania jej świadczenia, jej regularności, okresowości lub ciągłości. Okoliczność, że świadczenie usług ma charakter przejściowy, nie oznacza, że usługodawca nie może w przyjmującym państwie członkowskim korzystać z infrastruktury w zakresie koniecznym do jej wykonywania (sprawa C-55/94, Gebhard, pkt 25-27).

Rozróżnienie pomiędzy swobodą świadczenia przedsiębiorczości a swobodą świadczenia usług ma istotne znaczenie z punktu widzenia traktowania podmiotu pochodzącego z innego członkowskiego w przyjmującym państwie członkowskim. Państwo to nie może bowiem wymagać od osoby prowadzącej tymczasową działalność usługową spełnienia takich samych wymagań, których wymaga od osoby prowadzącej działalność o charakterze stałym. Działalność gospodarcza podlegająca swobodzie świadczenia usług jest zatem traktowana bardziej liberalnie niż działalność gospodarcza podlegająca swobodzie przedsiębiorczości.

$\mathrm{Z}$ punktu widzenia przedmiotu opinii należy wskazać, że zgodnie z art. 62 TFUE, na gruncie swobody przepływu usług mają zastosowanie przepisy traktatowe określające dopuszczalne ograniczenia swobody świadczenia przedsiębiorczości, przedstawione wcześniej. W świetle tych reguł można zatem stwierdzić, że prawo UE dopuszcza wprowadzenie ograniczeń na terenie przyjmującego państwa członkowskiego, dotyczących świadczenia usług pornograficznych $\mathrm{w}$ internecie podmiotom pochodzącym $\mathrm{z}$ innych państw członkowskich, jeżeli takie ograniczenia obowiązują również podmioty pochodzące z tego państwa.

\section{Swoboda przepływu towarów (art. 36 TFUE)}

Możliwość ustawowego ograniczenia dostępu do pornografii w internecie wymaga również przedstawienia przepisów art. 36 TFUE dotyczących swobody przepływu towarów. Można również przywołać orzecznictwo Trybunału Sprawiedliwości, w którym problematyka ta była analizowana począwszy od lat 80 . $\mathrm{XX}$ wieku, w związku z dopuszczalnymi ograniczeniami swobody importu towarów pornograficznych pomiędzy państwami członkowskimi.

Przytoczony art. 36 TFUE zezwala państwom członkowskim na wprowadzanie zakazów lub ograniczeń przywozowych, wywozowych lub transgranicznych 
uzasadnionych m.in. względami moralności publicznej. W kontekście wymogów poszanowania tego interesu publicznego Trybunał Sprawiedliwości analizował ograniczenia dotyczące importu materiałów pornograficznych. W literaturze przedmiotu wskazuje się, że ochrona moralności publicznej stanowi niezwykle delikatną materię związaną z wyjątkowo drażliwymi kwestiami, odwołującymi się do miejscowych norm kulturowych i społecznych. Problematyka standardów obowiązujących w zakresie moralności publicznej istotnie różni się w poszczególnych państwach członkowskich, w zależności do odmiennych uwarunkowań religijnych i obyczajowych ${ }^{2}$. Trybunał Sprawiedliwości stoi na stanowisku, że każde państwo członkowskie może samodzielnie określać, jakiego rodzaju zachowania są sprzeczne z moralnością publiczną (sprawa C-275, Schindler). Początkowo podchodził on do problematyki moralności publicznej w dość liberalny sposób. Za zgodny z art. 30 TFUE uznał zakaz importu czasopism pornograficznych z innych państw członkowskich, mimo iż sprzedaż i posiadanie tego rodzaju czasopism było dozwolone na terytorium Anglii i Walii (sprawa 34/79, R. p. Henn \& Darby). Następnie Trybunał Sprawiedliwości zaostrzył swoje stanowisko, traktując zakaz importu towarów obscenicznych za nieuzasadniony, jeżeli dotyczył wyłącznie towarów sprowadzanych z innych państw członkowskich. Przyjął, że w sytuacji, gdy państwo członkowskie nie zakazało sprzedaży i posiadania takich towarów na swoim terytorium, to w rzeczywistości temu państwu przyświecał inny cel niż zwalczanie pornografii (sprawa 121/85, Conegate). Z orzecznictwa Trybunału Sprawiedliwości wynika zatem, że w zakresie ocen dokonywanych na gruncie moralności publicznej państwom członkowskim przysługuje daleko idąca autonomia, której granice wyznaczają ogólne reguły dotyczące wprowadzania derogacji swobód rynku wewnętrznego, przedstawione wyżej.

\section{Możliwość ustawowego ograniczenia dostępu do pornografii w internecie zgodnie z przepisami UE odnoszącymi się do odpowiedzialności usługodawców będących pośrednikami (motywy 45 i 47 preambuły i art. 15 dyrektywy o handlu elektronicznym)}

Dyrektywa o handlu elektronicznym reguluje zagadnienia związane z prowadzeniem handlu elektronicznego, w tym: internetowych stron informacyjnych, sprzedaży, reklamy, usług świadczonych w ramach wolnych zawodów, usług rozrywkowych, usług pośrednictwa i usług finansowanych z reklam. Przedmiot opinii wymaga odwołania się do tiretów 45 i 47 preambuły oraz art. 15 dyrektywy, które zwalniają państwa członkowskie z obowiązków w zakresie nadzoru nad

A. Cieśliński, Wspólnotowe prawo gospodarcze, t. I, Swobody rynku wewnętrznego, Warszawa 2009, s. 802-803. 
usługodawcami świadczącymi usługi zwykłego przekazu (art. 12 dyrektywy), cachingu (art. 13 dyrektywy) i hostingu (art. 14 dyrektywy). Zakres tych usług wymaga wyjaśnienia.

Usługa zwykłego przekazu (art. 12 dyrektywy) stanowi usługę społeczeństwa informacyjnego ${ }^{3}$, polegającą na transmisji w sieci telekomunikacyjnej informacji przekazanych przez usługobiorcę lub na zapewnieniu dostępu do sieci telekomunikacyjnej. Czynności świadczone w ramach tej usługi obejmują automatyczne, pośrednie i krótkotrwałe przechowywanie informacji przekazywanych w zakresie, w jakim służy to wyłączenie wykonywaniu transmisji w sieci telekomunikacyjnej, jeżeli okres przechowywania nie przekracza czasu rozsądnie koniecznego do dokonania tej transmisji. Caching (buforowanie) (art. 13 dyrektywy) również stanowi usługę społeczeństwa informacyjnego, polegającą na transmisji w sieci telekomunikacyjnej informacji przekazanych przez usługobiorcę, dokonywany jest jednak w celu usprawnienia późniejszej transmisji informacji świadczonej na żądanie innych usługobiorców. Natomiast hosting (art. 14 dyrektywy) to także usługa społeczeństwa informacyjnego, która polega na przechowywaniu przez usługodawcę informacji przekazanych przez usługobiorcę. Szczegółowe wymogi świadczenia wskazanych usług określają przepisy powyżej wskazane, które nakładają na państwa członkowskie obowiązek zapewnienia, aby świadczący je usługodawcy nie odpowiadali za otrzymywane i przechowywane informacje.

Do zwolnienia usługodawców z odpowiedzialności za otrzymywane i przechowywane informacje odwołuje się art. 15 dyrektywy, zatytułowany „Brak ogólnego obowiązku w zakresie nadzoru”. Zgodnie z tym przepisem państwa członkowskie nie nakładają na usługodawców świadczących usługi zwykłego przekazu, cachingu i hostingu, określone w art. 12, art. 13 i art. 14 dyrektywy, ogólnego obowiązku nadzorowania informacji, które przekazują lub przechowują, ani ogólnego obowiązku aktywnego poszukiwania faktów i okoliczności wskazujących na bezprawną działalność.

Przepisów tych nie należy odczytywać jako oznaczających, że państwa członkowskie zobowiązane są powstrzymać się od wszelkiego rodzaju działań mających przeciwdziałać działalności przestępczej czy też wykrywać taką działalność

3 Zgodnie z definicją usługi społeczeństwa informacyjnego obejmuje ona wszystkie usługi świadczone normalnie za wynagrodzeniem, na odległość, za pomocą urządzeń elektronicznych do przetwarzania oraz przechowywania danych, na indywidualne żądanie usługobiorcy. Usługi te, określone w wykazie w załączniku V do dyrektywy 98/34/WE, które nie obejmują przetwarzania i przechowywania danych, nie są objęte przedstawioną definicją. Zob. dyrektywa 98/34/WE Parlamentu Europejskiego i Rady z 22 czerwca 1998 r. ustanawiająca procedurę udzielania informacji w zakresie norm i przepisów technicznych oraz zasad dotyczących usług społeczeństwa informacyjnego (Dz.Urz. UE L 204 z 21 lipca 1998 r., s. 37) oraz w dyrektywie 98/84/WE Parlamentu Europejskiego i Rady z 20 listopada 1998 r. w sprawie prawnej ochrony usług opartych lub polegających na warunkowym dostępie (Dz.Urz. UE L 320 z 28 listopada 1998 r., s. 54). 
prowadzoną na ich terenie przez usługobiorców omawianych usług społeczeństwa informacyjnego, w tym działalności pornograficznej w internecie. Wniosek ten znajduje potwierdzenie w przepisach omawianej dyrektywy i w orzecznictwie Trybunału Sprawiedliwości.

Po pierwsze, problematykę dopuszczalnych działań państw członkowskich $\mathrm{w}$ zakresie przeciwdziałania pornografii $\mathrm{w}$ internecie można rozpatrywać w związku z art. 3 ust. 1 dyrektywy, zatytułowanym „Rynek wewnętrzny”. Zgodnie z tym przepisem każde państwo członkowskie zapewnia, aby usługi społeczeństwa informacyjnego, świadczone przez usługodawcę mającego siedzibę na jego terytorium, były zgodne z przepisami krajowymi stosowanymi w tym państwie członkowskimi i wchodzącymi w zakres koordynowanej dziedziny ${ }^{4}$. W kontekście możliwości przeciwdziałania przez państwa członkowskie działalności pornograficznej w internecie na uwagę zasługuje art. 3 ust. 4 dyrektywy, w myśl którego państwa członkowskie mogą ograniczać swobodny przepływ usług społeczeństwa informacyjnego z powodów wchodzących w zakres koordynowanej dziedziny, jeżeli podejmowane przez nie środki są konieczne z powodu porządku publicznego, w szczególności zapobiegania przestępstwom, dochodzenia, wykrywania oraz ścigania przestępstw wraz z ochroną małoletnich oraz naruszeniem godności dotyczącej osób fizycznych.

Po drugie, problematykę przeciwdziałania pornografii w internecie można analizować w kontekście przepisów bezpośrednio dotyczących usług zwykłego przekazu, cachingu i hostingu (art. 12 ust. 3, art. 13 ust. 2 i art. 14 ust. 3 dyrektywy). Choć przepisy te zobowiązują państwa członkowskie do zwolnienia usługodawców z odpowiedzialności za przechowywane lub przekazywane przez nich informacje i ustalają związane z tym wymogi, to jednocześnie zastrzegają, że obowiązki te nie mają wpływu na możliwość wymagania od tych usługodawców przez sąd lub organ administracyjny, zgodnie z systemem prawnym państwa członkowskiego, żeby przerwali oni naruszenia prawa lub im zapobiegali. W przypadku usługi hostingu dodatkowo zastrzeżono, że państwa członkowskie mogą ustanowić procedury regulujące usuwanie lub uniemożliwianie dostępu do tych informacji przez te państwa.

4 Zgodnie z art. 2 lit. i dyrektywy koordynowana dziedzina dotyczy wymagań, które muszą być spełnione przez usługodawcę w związku z podjęciem działalności usługowej społeczeństwa informacyjnego, takich jak wymagania dotyczące kwalifikacji, zezwoleń lub zgłaszania i prowadzenia działalności polegającej na świadczeniu usług społeczeństwa informacyjnego, takich jak wymagania dotyczące zachowania usługodawcy, wymagania dotyczące jakości lub zawartość usługi, łącznie z mającymi zastosowanie do reklamy i umów, lub wymagania dotyczące odpowiedzialności usługodawcy. Koordynowana dziedzina nie obejmuje takich wymagań, jak: wymagania mające zastosowanie do towarów jako takich, wymagania mające zastosowanie do dostawy towarów i wymagania mające zastosowanie do usług, które nie są świadczone drogą elektroniczną. 
Po trzecie, działania państw członkowskich w zakresie zwalczania pornografii w internecie można również badać pod kątem art. 15 ust. 2 dyrektywy. Zgodnie z tym przepisem państwa członkowskie mogą ustanowić w stosunku do usługodawców świadczących usługi społeczeństwa informacyjnego obowiązek niezwłocznego powiadamiania właściwych władz publicznych o rzekomych bezprawnych działaniach podjętych przez ich usługobiorców lub przekazanych przez nich informacjach lub obowiązek przekazywania właściwym władzom, na ich żądanie, informacji pozwalających na ustalenie tożsamości ich usługobiorców, z którymi mają umowy o przechowywanie.

$\mathrm{Na}$ uwagę zasługują również przepisy preambuły dyrektywy, w szczególności motywy 26, 45 i 47. Zgodnie z motywem 26 preambuły dyrektywy państwa członkowskie mogą, zgodnie z warunkami ustanowionymi w tej dyrektywie, stosować krajowe przepisy prawa karnego oraz postępowania karnego, aby podjąć wszelkie środki dochodzeniowe i inne środki konieczne dla wykrycia i ścigania przestępstw, tak żeby nie było potrzeby powiadamiania o tych środkach Komisji. W myśl motywu 45 preambuły ograniczenia odpowiedzialności usługodawców będących pośrednikami, przewidziane w dyrektywie, nie mają wpływu na możliwości zakazów sądowych różnych typów. Zakazy takie mogą przybrać formę orzeczeń sądów lub innych organów administracyjnych wymagających, aby usunąć naruszenie prawa lub zapobiec każdemu naruszeniu prawa, łącznie $\mathrm{z}$ usunięciem bezprawnych informacji lub uniemożliwieniem dostępu do nich. Natomiast stosownie do motywu 47 państwa członkowskie nie mogą nakładać na usługodawców obowiązku nadzoru jedynie w odniesieniu do obowiązków o charakterze ogólnym. Nie dotyczy to obowiązków nadzoru mających zastosowanie do przypadków szczególnych oraz nie ma wpływu na decyzje władz krajowych podjęte zgodnie z ustawodawstwem krajowym.

Można również odwołać się do orzecznictwa Trybunału Sprawiedliwości dotyczącego zakresu odpowiedzialności spoczywającego na usługodawcy hostingu (art. 14 dyrektywy). Z wyroku w połączonych sprawach o sygn. akt C-236/08 do C-238/08, Google France SARL i inni wynika, że usługodawca nie jest odpowiedzialny za informacje przechowywane na żądanie usługodawcy w internecie, jeżeli przy świadczeniu swych usług nie odgrywał czynnej roli, która mogłaby sprawić, że będzie dysponował wiedzą o przechowywanych informacjach lub miał nad nimi kontrolę. Jeżeli usługodawca hostingu takiej roli nie odgrywa, nie może być pociągnięty do odpowiedzialności za treść przechowywanych, na żądanie reklamodawcy, informacji, chyba że powziąwszy wiadomość o bezprawnym charakterze tych informacji lub działalności reklamodawcy, nie podjął niezwłocznie odpowiednich działań w celu usunięcia wspomnianych informacji lub uniemożliwienia dostępu do nich.

Z przedstawionych przepisów dyrektywy i odnoszącego się do nich orzecznictwa Trybunału Sprawiedliwości wynika, że państwa członkowskie są upoważnione do prowadzenia zróżnicowanych działań mających na celu przeciwdzia- 
łanie i wykrywanie przestępczości prowadzonej w ramach świadczenia usług społeczeństwa informacyjnego, w tym pornografii w internecie. Omawiane przepisy wprowadzają wymóg, aby usługi te były świadczone zgodnie z krajowymi przepisami (art. 3 ust. 1 dyrektywy), oraz zakładają, że w zakresie penalizacji czynów zabronionych zastosowanie mają przepisy karne państw członkowskich (motyw 26 preambuły dyrektywy). Dyrektywa wyraźnie dopuszcza możliwość ograniczenia przez państwa członkowskie swobody przepływu usług społeczeństwa informacyjnego, jeżeli jest to konieczne z powodu porządku publicznego (art. 3 ust. 4 dyrektywy), do którego - zgodnie z orzecznictwem Trybunału Sprawiedliwości - zalicza się przeciwdziałanie pornografii. W myśl dyrektywy, aby przeciwdziałać przestępczości dokonywanej w ramach świadczenia usług społeczeństwa informacyjnego, państwa członkowskie mogą zarówno przyjmować wymogi prawne (przepisy krajowe), jak i podejmować działania indywidualno-konkretne, w postaci np. nakazu przerwania, na podstawie orzeczenia krajowego sądu lub organu administracyjnego, przez usługodawcę naruszeń prawa lub zapobiegania im (art. 12 ust. 3, art. 13 ust. 2 i art. 13 ust. 3 dyrektywy) lub też obowiązku niezwłocznego powiadomienia władz krajowych o bezprawnych działaniach podjętych przez usługobiorców lub o ich tożsamości (art. 15 ust. 2 dyrektywy). W konkluzji można zatem stwierdzić, że przytoczone przepisy dyrektywy nie zabraniają państwom członkowskim wprowadzania ograniczeń związanych ze świadczeniem transgranicznych usług społeczeństwa informacyjnego, mających na celu przeciwdziałanie i wykrywanie pornografii w internecie.

\section{Podsumowanie}

Traktatowe przepisy dotyczące swobód rynku wewnętrznego, w tym przepisy z zakresu przepływu przedsiębiorczości i świadczenia usług (art. 49 i art. 56 TFUE) oraz przepisy art. 15 dyrektywy 2000/31/WE Parlamentu Europejskiego i Rady z 8 czerwca 2000 r. w sprawie niektórych aspektów prawnych usług społeczeństwa informacyjnego, w szczególności handlu elektronicznego w ramach rynku wewnętrznego nie zabraniają państwom członkowskim wprowadzania ograniczeń związanych ze świadczeniem transgranicznych usług społeczeństwa informacyjnego mających na celu przeciwdziałanie i wykrywanie pornografii $\mathrm{w}$ internecie.

\section{Bibliografia}

Cieśliński A., Wspólnotowe prawo gospodarcze, t. I, Swobody rynku wewnętrznego, Warszawa 2009. 